\title{
セメンタイト/フェライト間の合金元素の 分配に対する磁性の效果
}

\author{
高 武 盛* 佐久間健人** 西 沢 泰二**
}

\begin{abstract}
Musong Ko, Taketo Sakuma and Taiji Nishizawa : Effect of Magnetism on the Partition of Alloying Elements between Cementite and Ferrite. It has been pointed out by Hillert et al. in 1967 that the partition of manganese between cementite and ferrite is markediy influenced by the magnetism of ferrite, and the temperature dependence of the partition coefficient shows an abnormal deviation from the ordinary Arrehnius equation in the vicinity of the Curie temperature. This work was intended to extend their idea to the other elements, and the partition coefficient of chromium, manganese, cobalt and nickel between cementite and ferrite at $700 \sim 500^{\circ} \mathrm{C}$ was measured. It was found that the partition coefficient of chromium and manganese increases considerably, and that of cobalt decreases abnormally as the equilibration temperature falls. In the case of nickel, the coefficient does scarcely show the sign of decrease contrary to the prediction from the Arrehnius equation. These findings are in good agreement with the theory proposed by Hillert et al. The partition of the elements between cementite and austenite was also studied, and a parameter $\Delta G_{\mathrm{M}}^{\alpha / \gamma \mathrm{Fe}}$ representing the effect on the relative stability of ferrite and austenite was evaluated.
\end{abstract}

(Received October 17, 1975)

\section{I. 緒言}

通常の錩はフェライト基質中にセメンタイト粒の分散し た組織の状態で使用されるので，鉬に添加された合金元素 がセメンタイトとフェライトの両相にどのような比率で固 溶しているかを明確にすることは特殊鋼の組織学に打ける 重要な課題の一つで放り，こ机までにる，Hultgren ら (1) や位藤ら ${ }^{(2)}$ をはじ多くの研究者によって央験がなされて きた，その結果，セメンタイトとフェライトの両相に固溶 する合金元素漕度の比率は各合金元素に固有の值であっ て，合金元素の添加量沉も，鋼の炭素含有量炕も依存しな い一定の值であることが確喼された，Table 1 は現在もっ ともひろく採用されている各合金元素の分配係数(禹相に おける重量\%の比)の值を表示したるのである。

上記のように合金元素がセメンタイト(以下 $\theta$ 相之略す) そフェライト(以下 $\alpha$ 相之略す)とに一定の此率で分配され るといら事実は，この分配現象が Nernst-Berthelot の分 配律と呼ばれる法則に従らことを示している。したがっ て，分配律の一般的な特性から判断するならば，分配係数 は合金元素に固有の值ではるるが，平衡化の温度に応して
変化すべきむので，その温度依存性はアレニウス形である らと推定してよいはずで古る。しかしながら, Darken

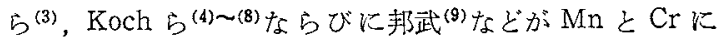
ついて行った実験值を整理してみると，平衡化温度の低下 に伴う分配係数の增加は異常とい党るほど急激であること

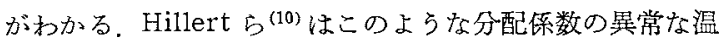
度传存性について熱力学的に解析し，その原因が $\alpha$ 相の磁 気変態に基づことをはじぬて指摘した。ただし，700 以下の温度に括ける合金元素の分配についての交献は潘注 前記のるのだけにかぎられていて，あまり豊富とはい党 ず，また，熱力学的解析に必要な基礎データも不充分で あったために，この問題についての考察が完全になされた とはいいがたい。

以上の理由から本研究では， $\theta / \alpha$ 間の合金元素の分配俰 数が $700^{\circ} \mathrm{C}$ 以下の温度でどのように变化するかを, Cr， $\mathrm{Mn}, \mathrm{Co}, \mathrm{Ni}$ の 4 つの元素について詳しく剆定し，さらに その結果をHillertらの手法にしたがって熱力学的に解析 することにより， $\alpha$ 相の強磁性と分配現象とのかかわりあ いを明確にしょうとすることを第一の目的とした。このほ かに本研究では，強磁性の影響のないオーステナイト(以

Tabie 1 Partition coefficient of alloying elements between cementite and ferrite at $700^{\circ} \mathrm{C}^{(1)(2)}$.

\begin{tabular}{c|c|c|c|c|c|c|c|c}
\hline Element & Cr & Mn & V & Mo & W & Ni & Co & Si \\
\hline$\left(\frac{w t \% \text { in cementite }}{\text { wt } \% \text { in ferrite }}\right)$ & 28.0 & 10.5 & 9.0 & 7.5 & 2.0 & 0.34 & 0.23 & 0.03 \\
\hline
\end{tabular}

* 東北大学大学院 (Graduate School, Tohoku University, Sendai)

** 東北大学工学部金属材料工学科(Department of Materials Science, Faculty of Engineering, Tohoku University, Sendai) 
下 $\gamma$ 相と略す)と $\theta$ 相間の合金元素の分配の滥度佧存性に ついても調べ，上記の $\theta / \alpha$ 間の分配についての結果と統合 して解析することにより， $\alpha / r$ 両相の平衡に関する基礎的 なパラメーター $\Delta G_{\mathrm{M}}^{\alpha / 7 \mathrm{Fe}}$ の值を演繹的に導出し，これまで に報告されている $\Delta G_{M}^{\alpha / \gamma \mathrm{Fe}}$ の值との対照以ついて子言及 する。

\section{II. セメンタイトとフェライト(または オーステナイト)間の分配係数}

\section{1. 実験試料}

電解鉄 $(99.95 \%)$ ，電解クロム $(99.2 \%)$ ，電解マンガン (99.9\%)，モンドコバルト (99.9\%) 执よびモンドニッケル $(99.9 \%)$ と，西らかじめ溶製した白銑 (3.6\% C)を素材と して，Table 2 亿示したよらな組成を持つ 11 種類の試料 をアルゴン雾团気中で高周波溶解した，同表中の F1〜F7 の試料は $\theta / \alpha$ 平衡の実験に供したもので，孷素量を約 0.5 $\mathrm{wt} \%$ とし，特殊宸化物を作りやすい $\mathrm{Cr}$ につては $\theta$ 相 一の最大固溶度 ${ }^{(2)}$ を考慮してその添加量を䄪 $1 \mathrm{wt} \%$ にと ぞめた。またA 1 A 4 の試料は $\theta / \gamma$ 平衡の実験に供した もので，いずれの試料にも約 $0.4 \mathrm{wt} \%$ の $\mathrm{Cr}$ 㬄加して あるが，これは長時間の平衡化による琴鉛化を防止すると ともに，Cr自身の分配を調べるためのるのである。なお $\theta$ 相と $r$ 相間の Mn 7 分配についてはすでに詳しい実験が Hillert ら ${ }^{(10)}$ 亿よってなされているので,ここでは $\mathrm{Cr}$, $\mathrm{Co}, \mathrm{Ni}$ を含を陚料のみを用意した。

Table 2 Chemical composition of specimens(wt \%).

\begin{tabular}{c|c|c|c|c|c}
\hline \hline Alloy No. & C & Cr & Mn & Co & Ni \\
\hline F 1 & 0.46 & 0.29 & - & - & - \\
F 2 & 0.42 & 1.09 & - & - & - \\
F 3 & 0.47 & - & 0.93 & $\overline{-}$ & - \\
F 4 & 0.46 & - & - & 1.01 & - \\
F 5 & 0.51 & - & - & 2.88 & - \\
F 6 & 0.50 & - & - & - & 1.00 \\
F 7 & 0.52 & - & - & - & 3.03 \\
\hline A 1 & 2.04 & 0.41 & - & 0.99 & - \\
A 2 & 1.52 & 0.38 & - & 0.97 & - \\
A 3 & 2.11 & 0.45 & - & - & 1.20 \\
A 4 & 1.49 & 0.41 & - & - & 1.15 \\
\hline
\end{tabular}

\section{2. 実験方法}

(1) セメンタイトとフェライトの平衡実験

熱間鐉造した各試料から $8 \mathrm{~mm} \phi \times 80 \mathrm{~mm}$ の丸棒を切出 し, 真空炉で $950^{\circ} \mathrm{C} 1 \mathrm{hr}$ の溶体化を行ない,ついで $850^{\circ} \mathrm{C}$ まで沪冷してから水獟入れし，ただらに液体堂素に約 30 min 間浸漬して完全なマルテンサイト組織とした。これら の焼入状態に古る各試片を透明石英管中に約 $1 / 3$ 気压のア ルゴンと共に封入し, $700 \sim 500^{\circ} \mathrm{C} て ゙ 50^{\circ} \mathrm{C}$ 間隔ごとの温度 で長洔間の焼戻しを行って， $\theta$ 相と $\alpha$ 相との平衡状態に到 達するようにした。この際の平衡化の時間は各温度に甜け る合金元素の拡散係数の值を参考化乙，充分化平衡化乙得
ると予想される二通りの牌問を選び，两試料についての絬 果を対比して完全平衡に趭したことを確恋した。 $\theta$ 相の組 成の沠定は従来の研究と同様電解分醀法 ${ }^{(11)}$ に上って抽 出した $\theta$ 相を化学分析すること仙より行った。さらに分配 俰数の位は，以上の上うにして求められた $\theta$ 相中の合金元 素濃度と，試料中の岮素濃度から推定さ机る $\theta$ 相の存在量 とから， $\alpha$ 相中の合金元素濃度を計算し，両者の比をとる ことによって決定した。

（2）セメンタイトとオーステナイトとの平衡実験

鋳造したままの各陚料から $8 \mathrm{~mm} \phi \times 8 \mathrm{~mm}$ の丸棒を切

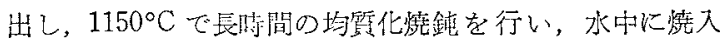
れたものを試片として使用した，平衡化の温度は 1100 , $950,800^{\circ} \mathrm{C}$ でり，分配平衡が達成されると尒想される よりもさら長洔問の平衡化を行った。この理由は， $\gamma$ 相 と平衡する $\theta$ 相を純粋な形で鋼中から電解分罚することは 困難であるとが知られているので(11)，X線マイクロフ ナライザーによって $\theta$ 相中の合金元素を分析する必要上， 直径約 10 ミクロン以上の大きさに $\theta$ 相の粒子を成長させ ねばならなかったためである。使用したX線マイクロフナ ライザーは島津製 ARL-EMX 型で，特性X線の取出解は $52.5^{\circ}$ で势り,加速電压 $20 \mathrm{kV}$, 試料電流 $0.03 \mu \mathrm{A}$ の条件 下で点分析を行的た。分析に用いた分光繀晶は Cr $K \alpha_{1}$ 線 については石英結晶，Co, Ni の $K \alpha_{1}$ 線については LiF 結 晶で要る。

分析に先立って, Cr，Coならびに Ni る Fe-M 2 元合金を用いて，澧度と特性X線の強度との関 係を求めるための補足実験を行い，各元素についての検量 式が次のように得られた。

$$
\begin{aligned}
& C_{\mathrm{Cr}}=73.7 \times\left(I / I_{0}\right) \mathrm{Cr} \\
& C_{\mathrm{Co}}=100.6 \times\left(I / I_{0}\right) \mathrm{Co} \\
& C_{\mathrm{Ni}}=122.7 \times\left(I / I_{0}\right)_{\mathrm{Ni}}
\end{aligned}
$$

ここで $C_{i}(i=\mathrm{Cr}, \mathrm{Co}, \mathrm{Ni})$ は $i$ 元素の重量\%，(I/I $)_{i}$ は $\theta$ 相または $\gamma$ 相中心固溶している $i$ 元素の特性X線と純粋状 態に打ける先れとの相対强度比である。な和平衡試料の分 析に際しては，純 $\mathrm{Fe}-\mathrm{C} 2$ 元系の試料熱処理して $\theta+\gamma$ の2相組織としたものを用いてバックグランドの補正を行 った。

\section{3. 実験結果}

(1) セメンタイトとフェライト(またはオーステナイト) 間の合金元素の分配

$700 \sim 500^{\circ} \mathrm{C}$ で平衡化した試料中の $\theta$ 相を分析して得ら れた合金元素湛度 $C_{M}^{\theta}(\mathrm{wt} \%)$ と，その值にもとついてて計算 した $\alpha$ 相の合金元素濃度 $C_{\mathrm{M}}^{\alpha}(\mathrm{wt} \%)$ とを Table 3 に示し

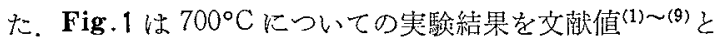
比較したもので，両者にきわめて良い一致が見られる。 た $r$ 相ならびにこれと平衡する $\theta$ 相中の $\mathrm{Cr}, \mathrm{Co}, \mathrm{Ni}$ の濃 度をX線マイクロアナライザーによって分析した結果は

Table 4 に示寸と拉りである。 
Table 3 Partition of alloying elements between cementite and ferrite.

\begin{tabular}{|c|c|c|c|c|c|c|c|c|c|}
\hline Element & Equilibration & $\begin{array}{l}\text { Alloy } \\
\text { No. }\end{array}$ & $C_{\mathrm{M}}^{\theta}(\mathrm{wt} \%)$ & $C_{\mathrm{M}}^{\alpha}(\mathrm{wt} \%)$ & $C_{M}^{\theta} / C_{M}^{\alpha}$ & $y_{M}^{\theta}$ & $x_{\mathrm{M}}^{a}$ & $K_{\mathrm{M}}^{\theta / \alpha^{\dagger}}$ & $A_{\mathrm{M}}^{\theta / \alpha}$ \\
\hline $\mathrm{Cr}$ & $\begin{array}{l}700^{\circ} \mathrm{C} \times 10 \mathrm{hr} \\
650^{\circ} \mathrm{C} \times 40 \mathrm{hr} \\
600^{\circ} \mathrm{C} \times 40 \mathrm{hr} \\
550^{\circ} \mathrm{C} \times 2000 \mathrm{hr} \\
500^{\circ} \mathrm{C} \times 30000 \mathrm{hr} \\
\times 1000\end{array}$ & $\begin{array}{ll}F & 1 \\
F & 2 \\
F & 1 \\
F & 2 \\
F & 1 \\
F & 2 \\
F & 1 \\
F & 2 \\
F & 1 \\
F & 2\end{array}$ & $\begin{array}{r}2.76 \\
10.95 \\
3.14 \\
12.33 \\
3.36 \\
13.59 \\
3.62 \\
14.75 \\
4.02 \\
14.89\end{array}$ & $\begin{array}{l}0.11 \\
0.44 \\
0.08 \\
0.34 \\
0.068 \\
0.25 \\
0.044 \\
0.18 \\
0.020 \\
0.17\end{array}$ & $\begin{array}{r}25.09 \\
24.89 \\
39.25 \\
36.27 \\
49.41 \\
54.36 \\
82.27 \\
81.94 \\
201.0 \\
87.59\end{array}$ & $\begin{array}{l}0.0317 \\
0.1250 \\
0.0361 \\
0.1407 \\
0.0386 \\
0.1549 \\
0.0413 \\
0.1679 \\
0.0462 \\
0.1695\end{array}$ & $\begin{array}{l}0.0011 \\
0.0044 \\
0.0008 \\
0.0034 \\
0.0006 \\
0.0025 \\
0.0004 \\
0.0018 \\
0.0002 \\
0.0017\end{array}$ & $\begin{array}{l}29.73 \\
32.48 \\
46.88 \\
48.15 \\
67.00 \\
73.32 \\
97.95 \\
112.1 \\
242.0 \\
120.1\end{array}$ & $\begin{array}{l}6558 \\
6729 \\
7057 \\
7106 \\
7294 \\
7450 \\
7497 \\
7718 \\
8431 \\
7353\end{array}$ \\
\hline $\mathrm{Mn}$ & $\begin{array}{l}700^{\circ} \mathrm{C} \times 10 \mathrm{hr} \\
650^{\circ} \mathrm{C} \times 40 \mathrm{hr} \\
600^{\circ} \mathrm{C} \times 200 \mathrm{hr} \\
550^{\circ} \mathrm{C} \times 3000 \mathrm{hr}\end{array}$ & $\begin{array}{ll}\mathrm{F} & 3 \\
\mathrm{~F} & 3 \\
\mathrm{~F} & 3 \\
\mathrm{~F} & 3\end{array}$ & $\begin{array}{l}5.98 \\
6.53 \\
7.78 \\
9.16\end{array}$ & $\begin{array}{l}0.55 \\
0.51 \\
0.41 \\
0.31\end{array}$ & $\begin{array}{l}10.87 \\
12.80 \\
18.98 \\
29.55\end{array}$ & $\begin{array}{l}0.0652 \\
0.0712 \\
0.0848 \\
0.0998\end{array}$ & $\begin{array}{l}0.0056 \\
0.0052 \\
0.0041 \\
0.0031\end{array}$ & $\begin{array}{l}12.46 \\
14.74 \\
22.60 \\
35.76\end{array}$ & $\begin{array}{l}4877 \\
4935 \\
5409 \\
5849\end{array}$ \\
\hline Co & $\begin{array}{l}700^{\circ} \mathrm{C} \times 10 \mathrm{hr} \\
650^{\circ} \mathrm{C} \times 40 \mathrm{hr} \\
600^{\circ} \mathrm{C} \times 200 \mathrm{hr}\end{array}$ & $\begin{array}{ll}\mathrm{F} & 4 \\
\mathrm{~F} & 5 \\
\mathrm{~F} & 4 \\
\mathrm{~F} & 5 \\
\mathrm{~F} & 4 \\
\mathrm{~F} & 5\end{array}$ & $\begin{array}{l}0.28 \\
0.69 \\
0.24 \\
0.61 \\
0.22 \\
0.39\end{array}$ & $\begin{array}{l}1.06 \\
3.06 \\
1.07 \\
3.07 \\
1.07 \\
3.09\end{array}$ & $\begin{array}{l}0.264 \\
0.226 \\
0.224 \\
0.199 \\
0.206 \\
0.126\end{array}$ & $\begin{array}{l}0.0029 \\
0.0070 \\
0.0024 \\
0.0062 \\
0.0022 \\
0.0040\end{array}$ & $\begin{array}{l}0.0101 \\
0.0291 \\
0.0101 \\
0.0291 \\
0.0101 \\
0.0293\end{array}$ & $\begin{array}{l}0.280 \\
0.236 \\
0.239 \\
0.208 \\
0.219 \\
0.132\end{array}$ & $\begin{array}{l}-2461 \\
-2792 \\
-2625 \\
-2880 \\
-2634 \\
-3513\end{array}$ \\
\hline $\mathrm{Ni}$ & $\begin{array}{l}700^{\circ} \mathrm{C} \times 10 \mathrm{hr} \\
675^{\circ} \mathrm{C} \times 20 \mathrm{hr} \\
650^{\circ} \mathrm{C} \\
600^{\circ} \mathrm{C} \times 40 \mathrm{hr} \\
\times 200 \mathrm{hr}\end{array}$ & $\begin{array}{ll}\text { F } & 6 \\
\text { F } & 7 \\
\text { F } & 6 \\
\text { F } & 7 \\
\text { F } & 6 \\
\text { F } & 7\end{array}$ & $\begin{array}{l}0.38 \\
0.98 \\
0.37 \\
0.94 \\
0.37 \\
0.89\end{array}$ & $\begin{array}{l}1.05 \\
3.20 \\
1.05 \\
3.21 \\
1.05 \\
3.21\end{array}$ & $\begin{array}{l}0.362 \\
0.306 \\
0.352 \\
0.293 \\
0.352 \\
0.277\end{array}$ & $\begin{array}{l}0.0039 \\
0.0100 \\
0.0038 \\
0.0096 \\
0.0038 \\
0.0091\end{array}$ & $\begin{array}{l}0.0100 \\
0.0305 \\
0.0100 \\
0.0306 \\
0.0100 \\
0.0306\end{array}$ & $\begin{array}{l}0.385 \\
0.321 \\
0.375 \\
0.307 \\
0.375 \\
0.288\end{array}$ & $\begin{array}{l}-1845 \\
-2141 \\
-1799 \\
-2166 \\
-1701 \\
-2159\end{array}$ \\
\hline
\end{tabular}

$\dagger K_{\mathrm{M}}^{\theta / \alpha}=\left(y_{\mathrm{M}}^{\theta} / y_{\mathrm{Fe}}^{\theta}\right) /\left(x_{\mathrm{M}}^{\alpha} / x_{\mathrm{Fe}}^{\alpha}\right)$ †ो $A_{\mathrm{M}}^{\theta / \alpha}=\Delta G_{\mathrm{M}}^{\alpha \rightarrow \theta}+\Omega_{\mathrm{FeM}}^{\alpha}-\Omega_{\mathrm{FeM}}^{\theta}$

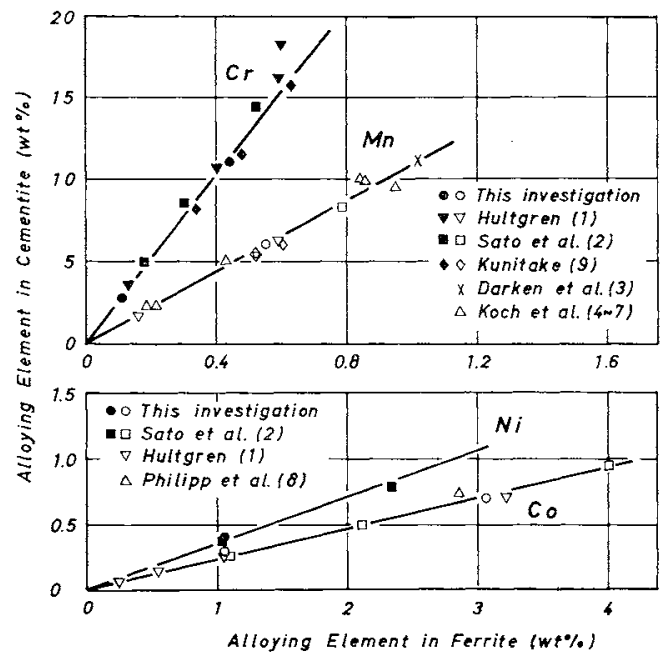

Fig.1 Partition of alloying elements between cementite and ferrite at $700^{\circ} \mathrm{C}$.

\section{（2）分配係数の温度依存性}

$\theta / \alpha$ 間の分配に関する初期の研究は，分配係数が湿度に よってそれ汪ど変化しないであろらという予想と，実験温 度の低下と共に平衡化に长顷閒の加熱を必要とするなどの

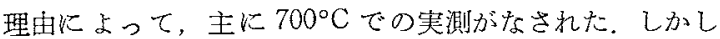
Darken ら (3)をはじめるする二，三の研究者(4)〜(9)によっ て分配係数が温度によって著しく変化することが明らかに された，Fig.2３はＴable 3 に示した本研究の結果とこ
れらの文献值とを合わせて示したもので, 平衡化温度の低 下に伴って， $\mathrm{Cr}, \mathrm{Mn}$ の分配係数は著しく大きくなり，Co については逆に小さくなることがわかる，乙かしNiの分 配係数は平衡化温度によってあまり变化しない。

一方， $\theta / \gamma$ 間の分配はX線マイクロアナライザーを用い ることによって正確に調べられるよらになったが，まだそ の報告数は非常に少ない.Fig.4,5は Table 4 に示した 本研究の結果と徒来の文献值 ${ }^{(3)}$ (10) (12) (15) とを合わせて示 したもので，各合金元素の分配係数は $\theta / \alpha$ 間の場合とほぼ 同栏の傎向をもって変化するが，しかしその変化の度合は あまり急激ではない。

\section{III． 分配現象の熱力学的解析}

\section{1. 正則溶体近似法による分配現象の記述}

(1) フェライト相ならびにオーステナイト相における 各成分の化学ポテンシャル

$\mathrm{Fe}-\mathrm{C}-\mathrm{M} 3$ 元 系固溶体は Fe-M 系置換型固溶体中KC 原子が侵入型固溶したもので，䈯密には正則溶体ではな い，しかし，CならびにMの濃度が低い領域では正則溶体 近似によって熱力学関数を記述しても，本質的な支障をき たさないことが知られているので(12)(16)，ここでも正則溶

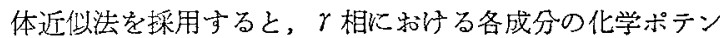
シャルは微小項を省略して次式によって近似される(10)(12).

$$
\begin{aligned}
& \mu_{\mathrm{Fe}}^{\gamma} \approx{ }^{0} G_{\mathrm{Fe}}^{\gamma}+R T \ln x_{\mathrm{Fe}}^{\gamma} \\
& \mu_{\mathrm{C}}^{\gamma} \approx{ }^{0} G_{\mathrm{C}}^{\gamma}+Q_{\mathrm{FeC}}^{\gamma} \cdot\left(1-2 x_{\mathrm{C}}^{\gamma}\right)+R T \ln x_{\mathrm{C}}^{\gamma}
\end{aligned}
$$


Table 4 Partition of alloying elements between cementite and austenite.

\begin{tabular}{|c|c|c|c|c|c|c|c|c|c|}
\hline Element & Equilibration & $\begin{array}{c}\text { Alloy } \\
\text { No. }\end{array}$ & $C_{\mathrm{M}}^{\theta}(\mathrm{wt} \%)$ & $C_{M}^{\gamma}(w t \%)$ & $C_{\mathrm{M}}^{\theta} / C_{\mathrm{M}}^{\gamma}$ & $y_{M}^{\theta}$ & $x_{\mathrm{M}}^{\gamma}$ & $K_{M}^{\theta / r^{\dagger}}$ & $A_{M}^{\theta / r^{\dagger \dagger}}$ \\
\hline $\mathrm{Cr}$ & $\begin{array}{r}1100^{\circ} \mathrm{C} \times 200 \mathrm{hr} \\
950^{\circ} \mathrm{C} \times 300 \mathrm{hr} \\
800^{\circ} \mathrm{C} \times 700 \mathrm{hr} \\
\times 70\end{array}$ & $\begin{array}{ll}\mathrm{A} & 1 \\
\mathrm{~A} & 3 \\
\mathrm{~A} & 1 \\
\mathrm{~A} & 3 \\
\mathrm{~A} & 2 \\
\mathrm{~A} & 4\end{array}$ & $\begin{array}{l}1.79 \\
1.75 \\
1.71 \\
1.64 \\
1.82 \\
1.88\end{array}$ & $\begin{array}{l}0.38 \\
0.41 \\
0.28 \\
0.28 \\
0.22 \\
0.26\end{array}$ & $\begin{array}{l}4.67 \\
4.24 \\
6.05 \\
5.79 \\
8.24 \\
7.33\end{array}$ & $\begin{array}{l}0.0205 \\
0.0201 \\
0.0196 \\
0.0189 \\
0.0209 \\
0.0217\end{array}$ & $\begin{array}{l}0.0038 \\
0.0042 \\
0.0029 \\
0.0029 \\
0.0023 \\
0.0027\end{array}$ & $\begin{array}{l}5.01 \\
4.44 \\
6.44 \\
6.20 \\
8.86 \\
7.84\end{array}$ & 6100 \\
\hline Co & $\begin{array}{r}1100^{\circ} \mathrm{C} \times 200 \mathrm{hr} \\
950^{\circ} \mathrm{C} \times 300 \mathrm{hr} \\
800^{\circ} \mathrm{C} \times 700 \mathrm{hr}\end{array}$ & $\begin{array}{ll}\text { A } & 1 \\
\text { A } & 1 \\
\text { A } & 2\end{array}$ & $\begin{array}{l}0.52 \\
0.48 \\
0.42\end{array}$ & $\begin{array}{l}1.00 \\
1.07 \\
1.04\end{array}$ & $\begin{array}{l}0.52 \\
0.45 \\
0.40\end{array}$ & $\begin{array}{l}0.0053 \\
0.0049 \\
0.0042\end{array}$ & $\begin{array}{l}0.0088 \\
0.0097 \\
0.0095\end{array}$ & $\begin{array}{l}0.56 \\
0.48 \\
0.43\end{array}$ & -2160 \\
\hline $\mathrm{Ni}$ & $\begin{array}{r}1100^{\circ} \mathrm{C} \times 200 \mathrm{hr} \\
950^{\circ} \mathrm{C} \times 300 \mathrm{hr} \\
800^{\circ} \mathrm{C} \times 700 \mathrm{hr}\end{array}$ & $\begin{array}{l}\text { A } 3 \\
\text { A } 3 \\
\text { A } 4\end{array}$ & $\begin{array}{l}0.37 \\
0.32 \\
0.23\end{array}$ & $\begin{array}{l}1.23 \\
1.33 \\
1.25\end{array}$ & $\begin{array}{l}0.30 \\
0.24 \\
0.18\end{array}$ & $\begin{array}{l}0.0038 \\
0.0032 \\
0.0023\end{array}$ & $\begin{array}{l}0.0109 \\
0.0120 \\
0.0115\end{array}$ & $\begin{array}{l}0.32 \\
0.25 \\
0.20\end{array}$ & -3920 \\
\hline
\end{tabular}

$\dagger K_{\mathrm{M}}^{\theta / r}=\left(y_{\mathrm{M}}^{\theta} / y_{\mathrm{Fe}}^{\theta}\right) /\left(x_{\mathrm{M}}^{\gamma} / x_{\mathrm{Fe}}^{\gamma}\right) \quad$ †† $A_{\mathrm{M}}^{\theta / \gamma}=\Delta G_{\mathrm{M}}^{\gamma \rightarrow \theta}+\Omega_{\mathrm{FeM}}^{\gamma}-\Omega_{\mathrm{FeM}}^{\theta}$

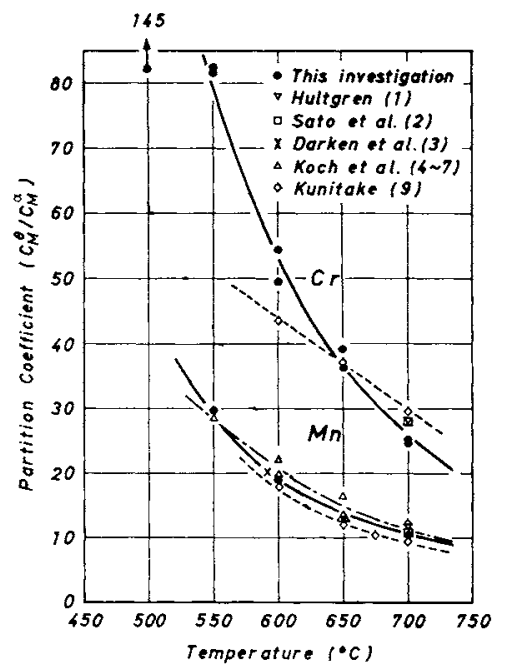

Fig.2 Temperature dependence of partition coefficient of $\mathrm{Cr}$ and $\mathrm{Mn}$ between cementite and ferrite.

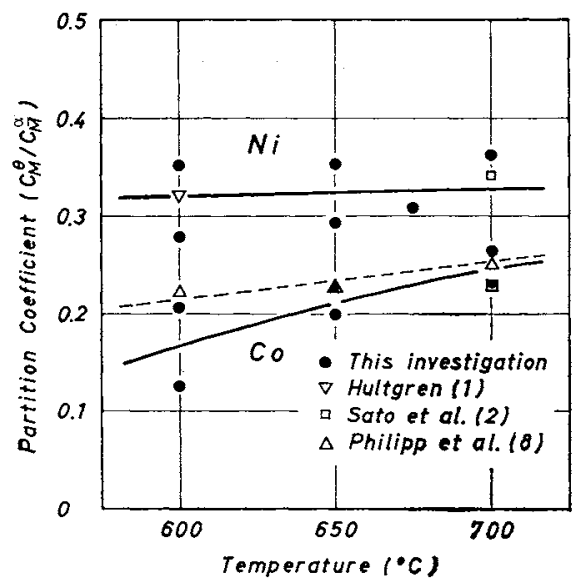

Fig.3 Temperature dependence of partition coefficient of $\mathrm{Co}$ and $\mathrm{Ni}$ between cementite and ferrite.

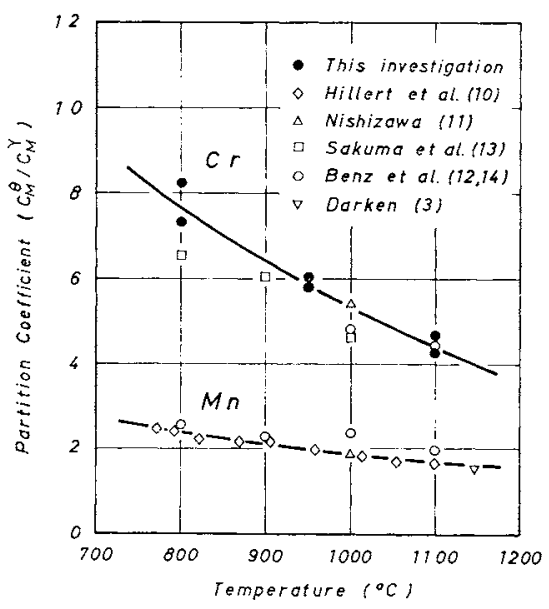

Fig.4 Temperature dependence of partition coefficient of $\mathrm{Cr}$ and $\mathrm{Mn}$ between cementite and austenite.

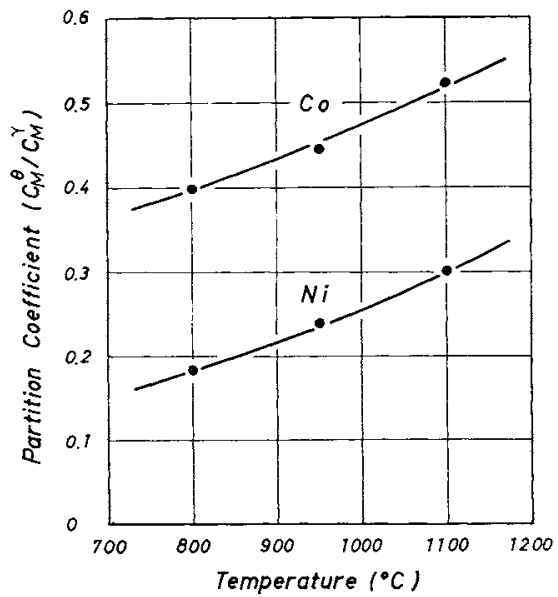

Fig.5 Temperature dependence of partition coefficient of $\mathrm{Co}$ and $\mathrm{Ni}$ between cementite and austenite. 
$\mu_{\mathrm{M}}^{\gamma} \approx{ }^{0} G_{\mathrm{M}}^{\gamma}+\Omega_{\mathrm{FeM}}^{\gamma}+W_{\mathrm{MC}}^{\gamma} \cdot x_{\mathrm{C}}^{\gamma}+R T \ln x_{\mathrm{M}}^{\gamma}$ ここで ${ }^{G} G_{i}^{\gamma}(i=\mathrm{Fe}, \mathrm{C}, \mathrm{M})$ は $i$ 成分が $f c c$ 構造を組んだ場 合の純粋状態に打る1モル当りの自由エネルギー， $Q_{\mathrm{FeC}}^{r}$

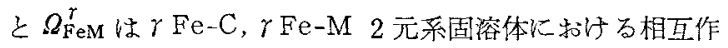
用パラメーター， $W_{\mathrm{MC}}^{\gamma}$ は $r$ 相中に敌沪る $\mathrm{M}$ 原子と $\mathrm{C}$ 原子 の相互作用パラィーターであり，また $x_{i}^{r}$ は成分の原子 分率である。

$\alpha$ 相に和ける各成分の化学 ポテンシャル飞ついて同様 に正則溶体近似法を適用し，C濃度が低いことを考虑して 微小項を略すと次式のよらに表わされる(10)(12)。

$$
\begin{aligned}
& \mu_{\mathrm{Fe}}^{\alpha} \approx{ }^{0} G_{\mathrm{Fe}}^{\alpha}+R T \ln x_{\mathrm{Fe}}^{\alpha} \\
& \mu^{\alpha} \approx{ }^{0} G_{\mathrm{C}}^{\alpha}+\Omega_{\mathrm{FeC}}^{\alpha}+R T \ln x_{\mathrm{C}}^{\alpha} \\
& \mu_{\mathrm{M}}^{\alpha} \approx{ }^{0} G_{\mathrm{M}}^{\alpha}+\Omega_{\mathrm{FeM}}^{\alpha}+R T \ln x_{\mathrm{M}}^{\alpha}
\end{aligned}
$$

（2）セメンタイト相における化学ポテンシャル

$\mathrm{Fe}-\mathrm{C}-\mathrm{M} 3$ 元系に打ける $\theta$ 相 $(\mathrm{Fe}, \mathrm{M})_{3} \mathrm{C}$ の熱力学関数 の近似は， $\theta$ 相を $\mathrm{Fe}_{3} \mathrm{C}$ と $\mathrm{M}_{3} \mathrm{C}$ とからなる擬 2 元系固溶 体とみなして，正則溶体近似法に上って記述する Richar一 dson ${ }^{(17)}$ の方法が現在一般的に採用されている(10)(12)(15). この近似法によると，低合金浱度域の $(\mathrm{Fe}, \mathrm{M}){ }_{3} \mathrm{C}$ 中に和け る $\mathrm{Fe}_{3} \mathrm{C}$ と $\mathrm{M}_{3} \mathrm{C}$ の化学ポテンシャルは次式炕よって表わ される。

$$
\begin{aligned}
& \stackrel{\theta}{\mu_{\mathrm{Fe}} \mathrm{C}} \approx{ }^{0} G_{\mathrm{Fe}_{3} \mathrm{C}}^{\theta}+\frac{3}{4} R T \ln y_{\mathrm{Fe}}^{\theta} \\
& \mu_{\mathrm{M}_{8} \mathrm{C}}^{\theta} \approx{ }^{0} G_{\mathrm{M}_{3} \mathrm{C}}^{\theta}+\frac{3}{4} \Omega_{\mathrm{FeM}}^{\theta}+\frac{3}{4} R T \ln y_{\mathrm{M}}^{\theta}
\end{aligned}
$$

ここで ${ }^{0} G_{\mathrm{Fe}_{3} \mathrm{C}}^{\theta}$ と ${ }^{0} G_{\mathrm{M}_{3} \mathrm{C}}^{\theta}$ は $\mathrm{Fe}_{3} \mathrm{C}$ と $\mathrm{M}_{3} \mathrm{C} 1$ グラム原子苏た りの自由エネルギー， $\Omega_{\mathrm{FeM}}^{\theta}$ は $(\mathrm{Fe}, \mathrm{M}){ }_{3} \mathrm{C}$ 中での $\mathrm{Fe}$ とM 原子との相互作用パラメーター， $y_{\mathrm{Fe}}^{\theta}$ と $y_{\mathrm{M}}^{\theta}$ は $\theta$ 相を構成 する金属原子中の $\mathrm{Fe}$ と $\mathrm{M}$ の占める割合 $\left(y_{\mathrm{M}}^{\theta}=x_{\mathrm{M}}^{\theta} /\left(x_{\mathrm{M}}^{\theta}+\right.\right.$ $\left.x_{\mathrm{Fe}}^{\theta}\right), y_{\mathrm{Fe}}^{\theta}=x_{\mathrm{Fe}}^{\theta} /\left(x_{\mathrm{M}}^{\theta}+x_{\mathrm{Fe}}^{\theta}\right)$ である。な打上式中に見られる 係数 3/4 は，FeとM西わせて $3 / 4$ グラム原子だけが置換 固溶し合らことに起因するものである。

\section{(3) セメンタイト/フェライトまたはセメンタイト/ オーステナイト間の分配式}

$\mathrm{Fe}-\mathrm{C}-\mathrm{M} 3$ 元系に括ける $\alpha$ 相季たは $\gamma$ 相と $\theta$ 相とが平衡 する場合には，各相の自由エネルギー曲面に共通の接面が 存在し，化学ポテンシ+ルの間に次の関係が成立しなけれ ばならない。

$$
\begin{aligned}
& 4 \mu_{\mathrm{Fe}_{3} \mathrm{C}}^{\theta}=3 \stackrel{\alpha \text { or } \gamma}{\mu_{\mathrm{Fe}}}+\mu_{\mathrm{C}}^{\alpha \text { or } r} \\
& 4 \mu_{\mathrm{M}_{3} \mathrm{C}}^{\alpha}=3 \mu_{\mathrm{M}}^{\alpha \text { or } r}+\mu_{\mathrm{C}}^{\alpha \text { or } \gamma}
\end{aligned}
$$

合金元素の分配を記述する式を得るにはまず(5-1)，(5-2) 両式から $\mu_{\mathrm{C}}$ に関する項を消去して，次式のよ5に変換す る.

$$
4\left(\mu_{\mathrm{Fe} 3}^{\theta} \mathrm{C}-\mu_{\mathrm{M}_{3} \mathrm{C}}^{\theta}\right)=3\left(\mu_{\mathrm{Fe}}^{\alpha \text { or } r}-\mu_{\mathrm{M}}^{\alpha \text { or } r}\right)
$$

次に，各成分の化学ポテンンャルの近似式(2),(3) およ び(4)を式(6)に代入して整理すると $\theta / \alpha$ なたは $\theta / r$ 間の 分配を表わす近似式が次のよらに求められる。

$$
K_{\mathrm{M}}^{\theta / \alpha}=\left(\frac{y_{\mathrm{M}}^{\theta}}{y_{\mathrm{Fe}}^{\theta}} / \frac{x_{\mathrm{M}}^{\alpha}}{x_{\mathrm{Fe}}^{\alpha}}\right) \approx \exp \left[\frac{\Delta G_{\mathrm{M}}^{\alpha \rightarrow \theta}+\Omega_{\mathrm{FeM}}^{\alpha}-\Omega_{\mathrm{FeM}}^{\theta}}{R T}\right]
$$

$$
\begin{aligned}
K_{\mathrm{M}}^{\theta / \gamma} & =\left(\frac{y_{\mathrm{M}}^{\theta}}{y_{\mathrm{Fe}}^{\theta}} / \frac{x_{\mathrm{M}}^{\gamma}}{x_{\mathrm{Fe}}^{\gamma}}\right) \\
& \approx \exp \left[\frac{\Delta G_{\mathrm{M}}^{\gamma \rightarrow \theta}+\Omega_{\mathrm{FeM}}^{\gamma}-\Omega_{\mathrm{FeM}}^{\theta}+W_{\mathrm{MC}}^{\gamma} \cdot x_{\mathrm{C}}^{\gamma}}{R T}\right]
\end{aligned}
$$

ここで $\Delta G_{\mathrm{M}}^{\alpha \rightarrow \theta}\left(\right.$ まは $\left.\Delta G_{\mathrm{M}}^{\gamma \rightarrow \theta}\right)$ は次式によって表わされる ハシメーターであり， $\alpha \mathrm{Fe}$ (または $\gamma \mathrm{Fe}$ ) と黒鉛とから 4/3 グラム原子の $\mathrm{Fe}_{3} \mathrm{C}$ が形成される場合の生成自由エネルギ 一と，M原子亡哭鉛とから 4/3 グラム原子の $\mathrm{M}_{3} \mathrm{C}$ が形成 される場合の生成自由エネルギーとの差に相当する。

$$
\begin{aligned}
\Delta G_{\mathrm{M}}^{\alpha \rightarrow \theta}= & \left(\frac{4}{3}{ }^{0} G_{\mathrm{Fe}_{3} \mathrm{C}}^{\theta}-{ }^{0} G_{\mathrm{Fe}}^{\alpha}-\frac{1}{3}{ }^{0} G_{\mathrm{C}}^{\mathrm{gr}}\right) \\
& -\left(\frac{4}{3}^{0} G_{\mathrm{M}_{3} \mathrm{C}}^{\theta}-{ }^{0} G_{\mathrm{M}}^{\alpha}-\frac{1}{3}{ }^{0} G_{\mathrm{C}}^{\mathrm{gr}}\right) \\
\Delta G_{\mathrm{M}}^{\gamma \rightarrow \theta}= & \left(\frac{4}{3}{ }^{0} G_{\mathrm{Fe}_{3} \mathrm{C}}^{\theta}-{ }^{0} G_{\mathrm{Fe}}^{\gamma}-\frac{1}{3}{ }^{0} G_{\mathrm{C}}^{\mathrm{gr}}\right) \\
& -\left(\frac{4}{3}^{0} G_{\mathrm{M}_{3} \mathrm{C}}^{\theta}-{ }^{0} G_{\mathrm{M}}^{\gamma}-\frac{1}{3}{ }^{0} G_{\mathrm{C}}^{\mathrm{gr}}\right)
\end{aligned}
$$

な和式(7)で表わされる $K_{\mathrm{M}}^{\theta / \alpha}$ (または $K_{\mathrm{M}}^{\theta / \gamma}$ )の値は，合金 元素濃度が微量のときには

$$
\begin{aligned}
& K_{\mathrm{M}}^{\theta / \alpha}=\left(\frac{y_{\mathrm{M}}^{\theta}}{y_{\mathrm{Fe}}^{\theta}} / \frac{x_{\mathrm{M}}^{\alpha}}{x_{\mathrm{Fe}}^{\alpha}}\right)_{x_{\mathrm{M} \rightarrow 0}^{\alpha} \approx} \approx \frac{y_{\mathrm{M}}^{\theta}}{x_{\mathrm{M}}^{\alpha}} \\
& K_{\mathrm{M}}^{\theta / r}=\left(\frac{y_{\mathrm{M}}^{\theta}}{y_{\mathrm{Fe}}^{\theta}} / \frac{x_{\mathrm{M}}^{\gamma}}{x_{\mathrm{Fe}}^{\gamma}}\right)_{x_{\mathrm{M} \rightarrow 0}^{\gamma} \approx \frac{y_{\mathrm{M}}^{\theta}}{x_{\mathrm{M}}^{\gamma}}}
\end{aligned}
$$

となるからこれらは $\theta / \alpha$ または $\theta / \gamma$ 間のM原子の分配係 数に相当するパラメーターに他ならない。

\section{2. 分配現象におよ你す強磁性の影響}

(1) 分配式中のパラメーターに対する磁性の効果

前節で得られた分配式 (7)，ならびKその関連式(8)に 含まれるパラメーターの中で ${ }^{0} G_{\mathrm{Fe}}^{\alpha} と \Omega_{\mathrm{FeM}}^{\alpha}$ の值はフェラ イト相以関するものであるから，磁気变態に際して異常変 化を示すと考光衫ばならない。亲ず ${ }^{0} G_{\mathrm{Fe}}^{\alpha}$ ，すなわち $\alpha$ Fe の 自由エネルギーに対する磁性の影響についてはZener ${ }^{(18)}$ をはじめ之する多くの研究者(19)(20)火よって解析され，自 由エネルギーを磁性の関与する項とそれ以外の項とに分解 して次式の上らに表方す方式が確立さ礼た。

$$
{ }^{0} G_{\mathrm{Fe}}^{\alpha}=\left[{ }^{0} G_{\mathrm{Fe}}^{\alpha}\right]_{\mathrm{Mag}}+\left[{ }^{0} G_{\mathrm{Fe}}^{\alpha}\right]_{\mathrm{NM}}
$$

Fig.6はWeiss ら ${ }^{(19)}$ とって計算された $\left[{ }^{0} G_{\mathrm{Fe}}^{\alpha}\right]_{\text {Mag }}$ の 値を、エンタルピーならびKエントロピーの磁性項の值と 共に図示したもので， $A_{2}$ 点以下゙の温度では強磁性にもと つく安定化の效果により， $\left[{ }^{0} G_{\mathrm{Fe}}^{\alpha}\right] \mathrm{Mag}$ の值は大きな負の值 をむつ. 温度上昇に伴って磁気エンタルピー $\left[{ }^{0} H_{\mathrm{Fe}}^{\alpha}\right]_{\mathrm{Mag}}$ の 值は增大し， $\alpha \mathrm{Fe}$ を不安定にしょうとするが，一方スピ ン配列の無秩序化による磁気エントロピー $\left[0 S_{\mathrm{Fe}}^{\alpha}\right]_{\mathrm{Mag}}$ の急 激な增加がみられるために，結局 $\left[{ }^{0} G_{\mathrm{Fe}}^{\alpha}\right] \mathrm{Mag}=\left\{\left[{ }^{0} H_{\mathrm{Fe}}^{\alpha}\right] \mathrm{Mag}\right.$ -T. $\left.\left[{ }^{0} \mathrm{~S}_{\mathrm{Fe}}^{\alpha}\right] \mathrm{Mag}\right\}$ の值は高温になるにつ就てさらに負の方 向に変化している。この上らな温度上昇化伴ら磁性項の特 有な变化の結果として $\alpha \mathrm{Fe}$ は $\mathrm{A}_{3} \sim \mathrm{A}_{4}$ の温度で一旦 $\gamma \mathrm{Fe}$ よりる不安定になるが， $A_{4}$ 点以上の温度で再び安定とな り，反相として出現することが明らがされた。

以上の解析結果を参照すると，磁珄に基つくく ${ }^{0} G_{\mathrm{Fe}}^{a}$ の值 


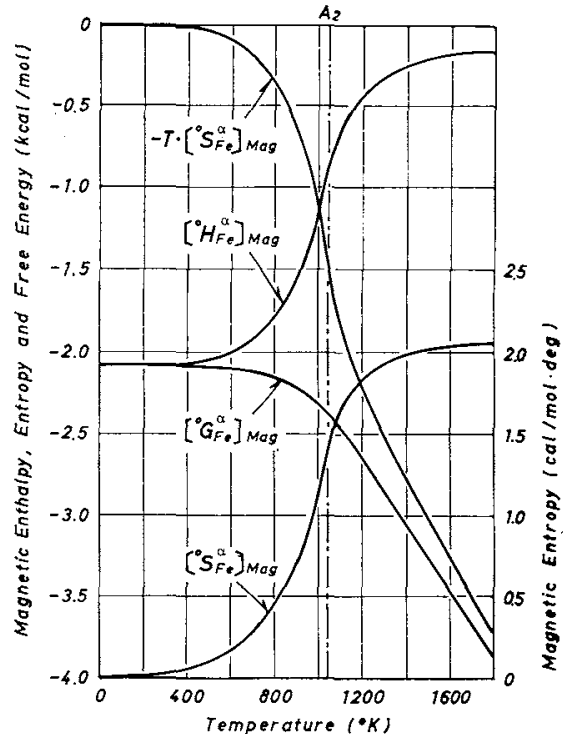

Fig.6 Magnetic terms in the thermodynamic functions of $\alpha$ iron (calculated by Weiss and Tauer $^{(19)}$ ).

の負の方向への変化に対応して，分配係数の値は全般的に 增加すると考兄られるが，乙かし，700～500 $\mathrm{C}$ の温度域 に特讨る $\left[{ }^{0} G_{\mathrm{Fe}}^{\alpha}\right]_{\text {Mag }}$ の值の変化はFig.6亿見られるように

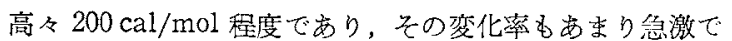
はないことから, 分配式 $(7)$ K打ける ${ }^{0} G_{\mathrm{Fe}}^{a}$ の磁性項の影 響は $\theta / \alpha$ 間の合金元素の分配にみられるよらな異常な温度

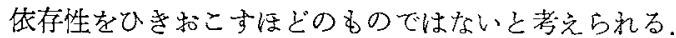

次に分配式(7)に和ける $\Omega_{\mathrm{FeM}}^{\alpha}$ の磁性との関連について 考察する。このパラメータ一は $\alpha$ 相中に扰胡る $\mathrm{Fe}$ 原子と M原子との相互作用，いいかえると Fe 原子と置換して M 原子が固溶したためのニネルギーの変化を表わするので, その磁性項は Fig.7に図式的に示したよらな温度低存性
Ferro-mag.

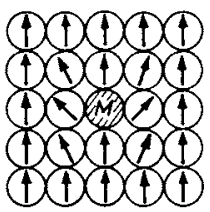

Para-mag

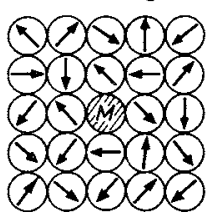

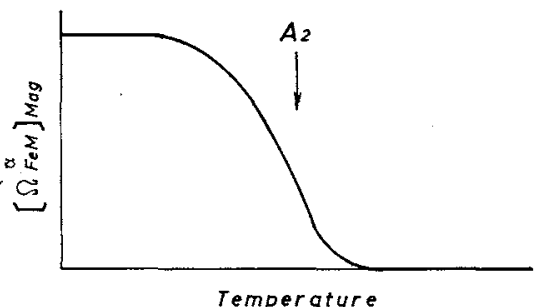

Fig.7 Anomaly in the temperature dependence of $\Omega_{\mathrm{FeM}}^{\alpha}$ due to the magnetic transition (schematic).
を持つと推定される。なぜならば，強磁性状態に执いて $\mathrm{Fe}$ 原子のスピソ閪化働く交換力以いわゆる協力現象的な あのであるから，そのエネルギーは $A_{2}$ 点の温庭を中心と するS字型の曲線によって画かれるはずで㐫り，M原子の 置換国溶はこの協力現像を乱す作用をするので， $\Omega_{\mathrm{FeM}}^{\alpha}$ の 磁性項は逆 S 字型の異常翌化をすると考えざるを得ないか らで妨る。ただしCoを添加した場合には例外的に磁気下 ピンのモーメントが增大するので(21)， $\Omega_{\mathrm{FeM}}^{\alpha}$ の磁性項は一 般の合金元素の場合々は迹に，S字型の变化を示すものと 推定される．Hillert ら ${ }^{(10)}$ は以上の上うな考方方を定量的 に表示卞る式を模䇣した結果，次のような， $\Omega_{\mathrm{FeM}}^{\alpha}$ を非磁 性項と磁性項とに分解した式を提示した。

$$
\Omega_{\mathrm{FeM}}^{\alpha}=\left[\Omega_{\mathrm{FeM}}^{\alpha}\right]_{\mathrm{NM}}+\left(\frac{d T_{\mathrm{C}}}{d x_{\mathrm{M}}^{\alpha}}\right) \cdot\left[{ }^{0} S_{\mathrm{Fe}}^{\alpha}\right]_{\mathrm{Mag}}
$$

ここで $d T_{\mathrm{C}} / d x_{\mathrm{M}}^{\alpha}$ はM原子の涯加による $\mathrm{A}_{2}$ 点の温度変化 率 $(\mathrm{deg} / \mathrm{mol})$ である。ただし著者ら ${ }^{(22)}$ の熱力学的解析によ ると式(10)性合金元素濃度が低い場合にのみ妥当である。

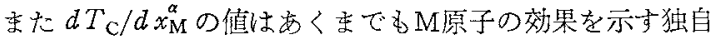
のパラメーターであって，現実の $\mathrm{A}_{2}$ 点记詨する影響とは かならずしる一致しない，本研究に用いた試料はいずれも

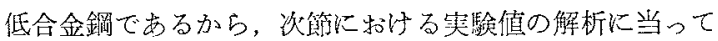
は $\Omega_{\mathrm{FeM}}^{\alpha}$ の近似式として式(10)を採用するが，その際 $d T_{\mathrm{C}} /$ $d x_{\mathrm{M}}^{\alpha}$ の陋は実駼值を説明するのに適するように定めるこ とにした。

\section{（2）実験値の解析}

以下の解析では，鼠初に，磁気变龍に基づく不確定要素 の少ない $\theta / r$ 䦓の分配次いて解析して就きこの結果に もとづいて $\theta / \alpha$ 間の分配平衡について検討する。この際の よりどころとする基本式は式（7）であるから，まず式(7-2) を次のように簡略化して和く。

$$
K_{\mathrm{M}}^{\theta / \gamma} \approx \exp \left\{\frac{A_{\mathrm{M}}^{\theta / \gamma}+W_{\mathrm{MC}}^{\gamma} \cdot x_{\mathrm{C}}^{\gamma}}{R T}\right\}
$$

ここで $A_{\mathrm{M}}^{\theta / r}=\Delta G_{\mathrm{M}}^{r \rightarrow \theta}+\Omega_{\mathrm{FeM}}^{r}-\Omega_{\mathrm{FeM}}^{\theta} て ゙$ あ。この $A_{\mathrm{M}}^{\theta / r}$ の 值を数值化するために, Table 4 に示した $\theta$ 相と $\gamma$ 相の合 金元素濃度をもとにして, 分配係数 $K_{\mathrm{M}}^{\theta / \gamma}\left[=\left(y_{\mathrm{M}}^{\theta} / y_{\mathrm{Fe}}^{\theta}\right) /\left(x_{\mathrm{M}}^{\gamma}\right.\right.$ $\left.\left.\mid x_{\mathrm{Fe}}^{\tau}\right)\right]$ の值を計算し，こ机をレニウス・プロットしたの が，Fig.8の高湿側の太い一点鎖線で西って，Mn, Co, Ni については極めて良い直線性が息られる。Cr の場合には 直線からわずかにはずれるが，この理由は後の式(12)に見 られるように， $W_{\mathrm{CrC}}^{T}$ の值が大きな温度依存性を有するこ とによる。これらのアレニウス・プロットの勾配から式 (11) 中の $A_{\mathrm{M}}^{\theta / r}+W_{\mathrm{MC}}^{\gamma} \cdot x_{\mathrm{C}}^{\gamma}$ の值を定め，さら飞 $W_{\mathrm{MC}}^{\gamma} \cdot x_{\mathrm{C}}^{\gamma}$ の 値を差引くことによって $A_{M}^{\theta / 7}$ の值を求めると, Table 4 の 最右闌に示したようにとれぞれの汇素についてほ涪一定の 值を持つことがわかったけ。この際，W $W_{\mathrm{MC}}^{\gamma}$ の值としてはFeC-M 3 元系 $\gamma$ 相中の炭素活量についての策驗佔(23) (26)

$\dagger \mathrm{Mn}$ についての值はHillert ら(10)によって $A_{\mathrm{M}}^{\theta / r}=$ 2490 と与えら級ている。 
を参照して，それぞれ次のように評価した。

$$
\begin{array}{ll}
W_{\mathrm{CrC}}^{\gamma}=-83060+45.21 T & (\mathrm{cal} / \mathrm{mol}) \\
W_{\mathrm{MnC}}^{\gamma}=-11000 & (\mathrm{cal} / \mathrm{mol}) \\
W_{\mathrm{CoC}}^{\gamma}+5800 & (\mathrm{cal} / \mathrm{mol}) \\
W_{\mathrm{NiC}}^{\gamma}=+15100-4.37 T & (\mathrm{cal} / \mathrm{mol})
\end{array}
$$

また，て相の焱素濃度 $x_{\mathrm{C}}^{\gamma}$ は，試料の合金元素濃度が低い のですべて $\mathrm{Fe}-\mathrm{C}$ 系に打けるすのと同一と仮定して， $x_{\mathrm{C}}^{\gamma}=0.0862\left(1100^{\circ} \mathrm{C}\right), x_{\mathrm{C}}^{\gamma}=0.0636\left(950^{\circ} \mathrm{C}\right), x_{\mathrm{C}}^{\gamma}=0.0435(800$ $\left.{ }^{\circ} \mathrm{C}\right)$ とした ${ }^{(16)}$. Fig. 8 に示した細い一点鎖線は，上記の数 值を式(11)に入れて，A $\theta / \gamma$ 間の分配係数を計算した結果を示したものである。

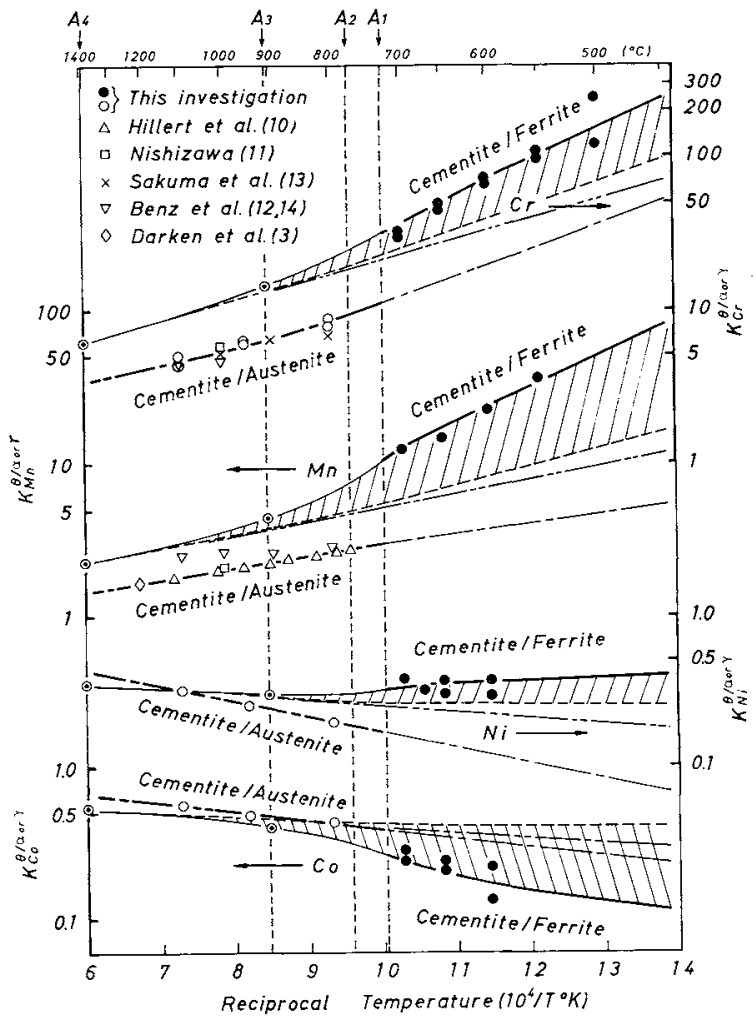

Fig. 8 Temperature dependnce of partition coefficient.

次に $\theta / \alpha$ 間の分配について検討する。(7-1)，(7-2)の両 式加ら知ら机るように，分配係数 $K_{\mathrm{M}}^{\theta / \alpha}$ 之 $K_{M}^{\theta / r}$ の間には次 の関係がある。

$K_{M}^{\theta / \alpha}=K_{M}^{\theta / r} \cdot \exp$

$$
\left\{\frac{\left({ }^{0} G_{\mathrm{Fe}}^{\gamma}-{ }^{0} G_{\mathrm{Fe}}^{\alpha}\right)-\left({ }^{0} G_{\mathrm{M}}^{\gamma}-{ }^{0} G_{\mathrm{M}}^{\alpha}+\Omega_{\mathrm{FeM}}^{\gamma}-\Omega_{\mathrm{FeM}}^{\alpha}\right)-W_{\mathrm{MC}}^{\gamma} \cdot x_{\mathrm{C}}^{\gamma}}{R T}\right\}
$$

上式中の ${ }^{0} G_{\mathrm{Fe}}^{\gamma}-{ }^{0} G_{\mathrm{Fe}}^{\alpha}$ は $\gamma \mathrm{Fe}$ と $\alpha \mathrm{Fe} の$ 自由エネルギー差 $\Delta^{0} G_{\mathrm{Fe}}^{\alpha \rightarrow r}$ であり，すで多くの研究者 ${ }^{(19)(20)}$ によって数值化 されている。亨た ${ }^{0} G_{\mathrm{M}}^{\gamma}-{ }^{0} G_{\mathrm{M}}^{\alpha}+\Omega_{\mathrm{FeM}}^{\gamma}-\Omega_{\mathrm{FeM}}^{\alpha}$ は合金元素M の $\alpha / \gamma$ 安定化パラメーター $\Delta G_{M}^{\alpha / 7 \mathrm{Fe}}$ と全く同等であっ て ${ }^{(27)}, A_{3}, A_{4}$ 点の温度に敊ける值はこれ李でのFe-M 2 元 系状態図の研究 ${ }^{(28) \sim(34)}$ から正確に推定される.したがって
式(13)は次のように書变えられる。

$$
\begin{aligned}
K_{\mathrm{M}}^{\theta / \alpha} & =K_{\mathrm{M}}^{\theta / \gamma} \cdot \exp \left\{\frac{\Delta G_{\mathrm{Fe}}^{\alpha \rightarrow \gamma}-\Delta G_{\mathrm{M}}^{\alpha / \gamma \mathrm{Fe}}-W_{\mathrm{MC}}^{\gamma} \cdot x_{\mathrm{C}}^{\gamma}}{R T}\right\} \\
& =\exp \left\{\frac{A_{\mathrm{M}}^{\theta / r}+\Delta^{0} G_{\mathrm{Fe}}^{\alpha \rightarrow \gamma}-\Delta G_{\mathrm{M}}^{\alpha / \gamma \mathrm{Fe}}}{R T}\right\}
\end{aligned}
$$

Fig.8の $\mathrm{A}_{3}$ 和よび $\mathrm{A}_{4}$ 点の温度に記したの印は，式(14)中 の各パラメーターにそれぞれの数值を入れて計算した值 でこ㚘らの温度に批るる仮想的な $\theta / \alpha$ 間の分配係数に相 当している.こ机らの点と，先得られた $A_{1}$ 点以下に特け る值，すなわら・印とを結ぶ線は，いずれの場合にも直線 そならず， $A_{2}$ 点近俊の温度で特異な变化を示している。

このような $K_{\mathrm{M}}^{\theta / \alpha}$ の值の異常な変化は前節で述べたよう

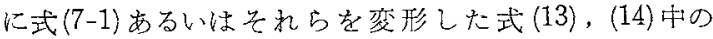
$\Omega_{\mathrm{FeM}}^{\alpha}$ の値が $\alpha$ 相の磁気変態に伴って異常变化するためで ある，そこで，式(14)中の $\Delta G_{\mathrm{M}}^{\alpha / 7 \mathrm{Fe}} \Omega_{\mathrm{FeM}}^{\alpha}$ の磁性项すな わち $\left(d T_{\mathrm{C}} / d x_{\mathrm{M}}^{\alpha}\right) \cdot\left[{ }^{0} S_{\mathrm{Fe}}^{\alpha}\right]_{\mathrm{Mag}}$, 号れ以外の温度に対して 1 次式で表わし得る項とに分解して

$$
\Delta G_{\mathrm{M}}^{\alpha / r \mathrm{Fe}}=\left[\Delta G_{\mathrm{M}}^{\alpha / r \mathrm{Fe}}\right]_{\mathrm{NM}}-\left(\frac{d T_{\mathrm{C}}}{d x_{\mathrm{M}}^{\alpha}}\right) \cdot\left[{ }^{0} S_{\mathrm{Fe}}^{\alpha}\right]_{\mathrm{Mag}}
$$

のように表わし，1400〜 500 Cのずで点が式(14)とよ く適合するように上式のハランーターの值をそれぞれ次の ように定めた。

$\left[\Delta G_{\mathrm{Cr}}^{\alpha / \gamma \mathrm{Fe}}\right]_{\mathrm{NM}}=-1730+0.22 T,\left(d T_{\mathrm{C}} / d x_{\mathrm{Cr}}^{\alpha}\right)=-715$ $\left[\Delta G_{\mathrm{Mn}}^{\alpha / r}\right]_{\mathrm{NM}}=-4500+0.96 T,\left(d T_{\mathrm{C}} / d x_{\mathrm{Mn}}^{\alpha}\right)=-1320$ $\left[\Delta G_{\mathrm{Co}}^{\alpha / \gamma \mathrm{Fe}_{\mathrm{e}}}\right]_{\mathrm{NM}}=+1440+0.37 T, \quad\left(d T_{\mathrm{C}} / d x_{\mathrm{Co}}^{\alpha}\right)=+1.030$ $\left[\Delta G_{\mathrm{Ni}}^{\alpha / \gamma \mathrm{Fe}}\right]_{\mathrm{NM}}=-3200+1.20 \mathrm{~T},\left(d T_{\mathrm{C}} / d x_{\mathrm{Ni}}^{\alpha}\right)=-400$

Fig.8中のハッチングの值は強磁性の出現に伴って生ずる $\Omega_{\mathrm{FeM}}^{\alpha}$ の磁珄項からの影響に対応するものであり，二点鎖 線は低温に和いても強磁性状態々はならない子仮定した場 合代予想さ礼る分配係数である。Fig.8で特に注意すべき 点は $\mathrm{Ni}$ と Co の分配係数が， $\theta / \alpha$ と $\theta / \gamma$ の場合に大小関 係が逆転していることであって，Table 1 にむ示したよう K， $\theta / \alpha$ 間の分配保数はNi の方が大さい。机に対して $\theta / \gamma$ 問の分配係数はCo の方が大さくなっている。この理 由はこれら両元素の分配に対する強磁性の効果が逆片向て

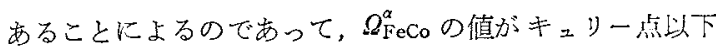
の温度で急激に負に， $\Omega_{\mathrm{FeNi}}^{a}$ が正に変化するためと考光ら れる。

\section{(3) $a / \gamma$ 安定化パラメーター $\Delta G_{M}^{\alpha / \gamma \mathrm{F}_{e}}$ の評価}

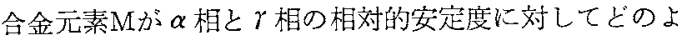
らな影響を与えるかを示すパラメーター $\Delta G_{\mathrm{M}}^{\alpha / r \mathrm{Fe}}$ は、鋼に 括ける合金元素の機能を表わす重要な因子であるために， これまでにす各種の方法によって定量化が試みられてき た ${ }^{(27)}$ 。ここでは Hillert ら ${ }^{(10)}$ の手法に従って， $\theta$ 相と $\alpha$ 相 または $\gamma$ 相間の分配平衡の実測值から $\Delta G_{M}^{\alpha / \gamma \mathrm{Fe}}$ の值を評 価する。この方法の特長は， $\alpha / \pi$ 间相間の平衡を实測乙難 いような温度に括注る゚゚ラメーターの值を熱力学的解析法 の利点を活かして間接的に導出生る点にあり，その基本式 
は式(13)，(14)を変形した次式によって与字られる。

$$
\begin{aligned}
\Delta G_{\mathrm{M}}^{\alpha / \gamma \mathrm{Fe}} & ={ }^{0} G_{\mathrm{M}}^{\gamma}-{ }^{0} G_{\mathrm{M}}^{\alpha}+\Omega_{\mathrm{FeM}}^{\gamma}-\Omega_{\mathrm{FeM}}^{\alpha} \\
& =R T \ln \left(K_{\mathrm{M}}^{\theta / \alpha} / K_{\mathrm{M}}^{\theta / \gamma}\right)-\Delta^{0} G_{\mathrm{Fe}}^{\alpha \rightarrow \gamma}+W_{\mathrm{MC}}^{\gamma} \cdot x_{\mathrm{C}}^{\gamma}
\end{aligned}
$$

上式により $\mathrm{Cr}, \mathrm{Mn}, \mathrm{Co}, \mathrm{Ni}$ の各元素についての $\Delta G_{\mathrm{M}}^{\alpha / \gamma \mathrm{Fe}}$ を計算した結果は Fig.9，10に示したとおりであって， $\mathrm{Cr}, \mathrm{Mn}, \mathrm{Ni}$ の $\Delta G_{\mathrm{M}}^{\alpha / r \mathrm{Fe}}$ は磁気的な効果によって, キュり 一点近傍から低温側に抽いて著しく真の方向に変化し， Co は近に正の方向炕変化していることがわかる。このこ とは次の上うに理解される。 Mn, Niはすべての温度で

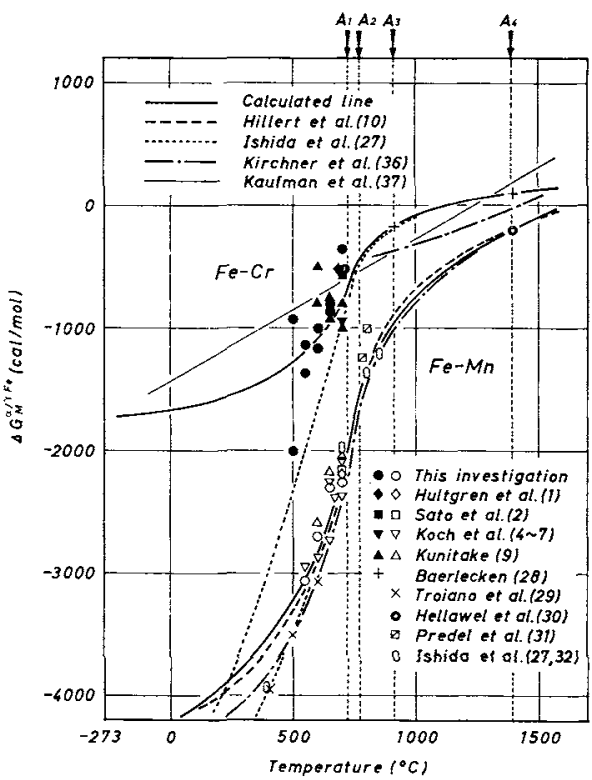

Fig.9 Temperature dependence of $\Delta G_{\mathrm{Cr}_{\mathrm{r}}}^{\alpha / 7 \mathrm{Fe}}$ and $\Delta G_{\mathrm{Mn}}^{\alpha / r \mathrm{Fe}}$.

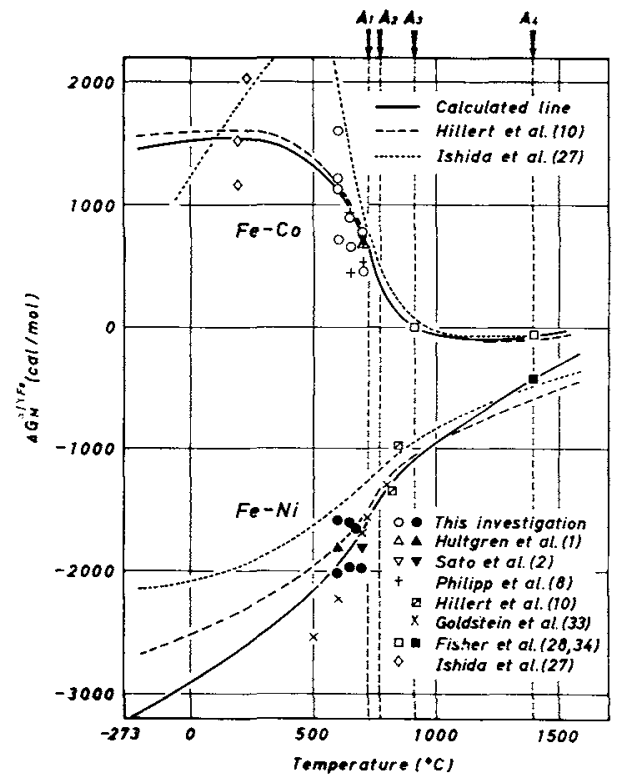

Fig.10 Temperature dependence of $\Delta G_{\mathrm{Co}_{0}}^{\alpha / \mathrm{Fe}}$ and $\Delta G_{\mathrm{Ni}}^{\alpha / F \mathrm{Fe}}$.
相を安定化するが，その傾向は $A_{2}$ 点以下の温度でさらに 強くなる。 $\mathrm{Cr}$ は $\mathrm{A}_{4}$ 点近傍の高温側で $\alpha$ 相安定化元素 であるが，温度が低くなるをて相を安定化するようにな り, 特に $A_{2}$ 点以下の温度で著しい。これに対してCoは 高温側では $\gamma$ 相を定定化するが，低温では強力な $\alpha$ 相安定 化元素に転ずる。このような $\alpha / \gamma$ 安定化パラメーターの異 常な温度依存性の根源が式(17)中の $\Omega_{\mathrm{FeM}}^{\alpha}$ の值に対する磁 気效果にあることは前記したと招りである。な㧊本結果と こ机亲で報告されている結果 ${ }^{(10)(27)(35) \sim(37)}$ とが全体的に 良く一致していることは，式(17)の関係を用いて， $\theta / \alpha な$ らびに $\theta / r$ 間の平衡実験により $\Delta G_{\mathrm{M}}^{\alpha / \gamma \mathrm{Fe}}$ の值を間接的に 導出した方法が適㚬なものであったことを示するのと考学 てょいであろう。

\section{IV. 総 括}

合金鋼に倾けるセメンタイトとフェライト間の合金元素 の分配に関する研究はこれ委で飞る数多く報告されてき た。しかしながら，分配係数の温度依存性汇注目した研究 はきわめて少ない，本研究では $\mathrm{Cr}, \mathrm{Mn}, \mathrm{Co}, \mathrm{Ni} の 4$ 元素 の分配係数を $700 \sim 500^{\circ} \mathrm{C}$ の温度で詳しく測定し，正則溶 体近似法に基うく熱力学的解析によって検部した，その結 果，キュリ一点近傍より低温側で $\mathrm{Cr}, \mathrm{Mn}$ の分配係数が急 激に增大し，また $\mathrm{C} 0$ の分配係数が急激に減少するような 異常な温度依存性が見出され，その原因がフェライト相の 強磁性にあることを明らかにした，一方，強磁性とのかか わり苛いのないセメンタイトとオ一ステナイト間の $\mathrm{Cr}$ ， Co，Ni の分配係数を測定した結果，その温度依存性は通 常のアレニウス形であることが確かめられた。これらの七 メンタイトとフェライトならびにセメンタイトとオーステ ナイト間の分配僠数に基ついて，合金元素がフェライトと オーステナイトのいずれを安定化するかを示すパラメータ - $\Delta G_{M}^{\alpha / \gamma \mathrm{Fe}}$ の值を導出し,このパラメーターに対しても フェライト相の强磁性の効果が明暸に表われることを示し た.

最後に本研究に熱心な御協力をいただいた東北大学工学 部学生並木邦夫氏(現，株式会社日本特殊錀研究所)ならび に同工学部加藤済正氏に深く感謝します。

\section{文献}

(1) A.Hultgren and K.Kuo : Mem.Sci.Rev.Met., $50(1953), 847$.

（2）佐藤知雄, 西沢泰二：金属学会誌，19(1955)，385.

(3) R.W.Gurry, J.Christakos and L.S. Darken: Trans. ASM, 53 (1961) , 187.

(4) W.Koch and H.Keller : Arch.Eisenhüttenw., 35 (1964), 1173.

(5) W.Koch, J.Dittmann and H.Keller : Arch.Eisenhüttenw., 39 (1968), 457.

(6) F.Leiber and W.Koch : Arch.Eisenhüttenw., $42(1971), 106$.

(7) H.El-Naggar and W.Koch : Arch.Eisenhüttenw., 44 (1973) , 609. 
(8) J.Philipp and W.Koch : Arch.Eisenhüttenw., $40(1969), 585$.

（9）邦武立郎：金属学会誌，29(1965)，653.

(10) M.Hillert, T.Wada and H.Wada : J.Iron Steel Inst., 205 (1967), 539.

(11) 佐滕知雄, 金子秀夫, 西㳄筷二：金属学会誌，19 (1955) , 336.

(12) T.Nishizawa : Thermodynamic Study of $\mathrm{Fe}-\mathrm{C}-$ $\mathrm{Mn}, \mathrm{Fe}-\mathrm{C}-\mathrm{Cr}$ and $\mathrm{Fe}-\mathrm{C}-\mathrm{Mo}$ Systems, Report 4602 , Swedish Board for Technical Development, Stockholm, (1967) .

(13) R.Benz, J. F. Elliott and J. Chipman : Met. Trans., $4(1973), 1975$.

（14）仿久間健人，熊金仁治，西沃泰二：鉄と鋼，60 (1974), 2153.

(15) R.Benz, J.F. Elliott and J. Chipman : Met. Trans., 5 (1974), 2235.

(16) 長谷部光弘，西沃泰二：金属学会誌，38(1974)，46.

(17) F.D.Richardson: J.Iron Steel Inst., 175 (1953), 33.

(18) C.Zener : J.Metals, 7(1955), 619

(19) R.J.Weiss and K.H.Tauer : Phys. Rev., 102 (1956), 1490.

(20) L.Kaufman, E.V.Clougherty and R.J.Weiss : Acta Met., 11 (1963), 323.

(21) W.M.Lomer and W.Marchall : Phil.Mag., 3 (1958), 185.

（22）兽 武盛，西沢泰二：金属学会誌に投稿予定。
(23) J.C.Greenbank: J.Iron Steel Inst., $209(1971)$, 986

(24) T.Wada, H.Wada, J.E.Elliott and J.Chipman: Met.Trans., 3(1972) , 1657.

(25) R.P.Smith : Trans. Met. Soc. AIME, 233 (1965), 397.

(26) K.Natesan and T.F.Kassner : Met.Trans., 4 (1973), 2557.

（27）石四清保，西沢泰二：金属学会誌，36(1972)，270.

(28) E.Baerlecken, W.A. Fischer and K.Lorenz: Stahl u.Eisen, 81 (1961), 768.

(29) A.R.Troiano and F. T.McGuire: Trans. ASM,

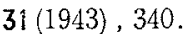

(30) A. Hellawell and W. Hume-Rothery : Phil. Trans. Soc.London, A 249(1957), 417.

(31) B.Predel and W.Gust : Arch. Eisenhüttenw., 43 (1972) , 721.

(32) 石田清保: : 東北大学大学院工学研究科博士論文, (1974).

(33) J.I.Goldstein and R.E.Ogilvie : Trans. Met. Soc.AIME, 233 (1965), 2083.

(34) W.A.Fischer, K.Lorenz and H.Fabritius : Arch.Eisenhüttenw., 37 (1966), 79.

(35) H.Harvig, G.Kirchner and M. Hillert : Met. Trans., $3(1972), 329$.

(36) G.Kirchner, T.Nishizawa and B. Uhrenius: Met.Trans., $4(1973), 167$.

(37) L. Kaufman and H.Nesor : Z.Metallk., 64 (1973), 249 .

\section{起電力法による $\mathrm{Co}_{3} \mathrm{~B}$ おび $\mathrm{Co}_{2} \mathrm{~B}$ の熱力学的性質の研究*}

\section{大森 慎一郎** 橋 本 䔨 彦**}

Shinichiro Omori and Yasuhiko Hashimoto : Studies on Thermodynamic Properties of $\mathrm{Co}_{3} \mathrm{~B}$ and $\mathrm{Co}_{2} \mathrm{~B}$ by e.m.f. Measurements. the cell,

$$
\left\langle\mathrm{Pt}>\mathrm{O}_{2} \text { in air }\left|\mathrm{ZrO}_{2} \cdot \mathrm{CaO}\right| \mathrm{Co}, \mathrm{Co}_{3} \mathrm{~B}\left(\text { or } \mathrm{Co}_{2} \mathrm{~B}\right), \mathrm{B}_{2} \mathrm{O}_{3}\langle\mathrm{Pt}\rangle\right. \text {, }
$$

by using a $\mathrm{Co}-\mathrm{B}$ alloy containing about 20 at $\% \mathrm{~B}$. The e.m.f.values were used in calculation of the thermodynamic properties of $\mathrm{Co}_{3} \mathrm{~B}$ and $\mathrm{Co}_{2} \mathrm{~B}$. The calculated thermodynamic properties are as follows :

$$
\begin{aligned}
& \left.\begin{array}{l}
\Delta G_{\mathrm{C}_{3} \mathrm{~B}}^{\circ}=-25229+4.775 T \pm 100 \mathrm{cal} / \mathrm{mol} \\
\Delta H_{\mathrm{CO}_{3} \mathrm{~B}}=-25229 \mathrm{cal} / \mathrm{mol} \\
\Delta S_{\mathrm{CO}_{3} \mathrm{~B}}=-4.775 \mathrm{e} . \mathrm{u} .
\end{array}\right\} \quad\left(1090 \sim 1200^{\circ} \mathrm{K}\right) \\
& \text { and } \\
& \Delta G_{\mathrm{Co}_{2} \mathrm{~B}}^{\circ}=-41322+19.172 T \pm 100 \mathrm{cal} / \mathrm{mol} \\
& \Delta H_{\mathrm{CO}_{2} \mathrm{~B}}^{\circ}=-41322 \mathrm{cal} / \mathrm{mol} \\
& \Delta S_{\mathrm{CO}_{2} \mathrm{~B}}^{\circ}=-19.172 \mathrm{e} . \mathrm{u} \text {. } \\
& \left(970 \sim 1150^{\circ} \mathrm{K}\right)
\end{aligned}
$$

In the diagram of the e.m.f.vs temperature, the intersection of a line for the system $\mathrm{Co}+\mathrm{CO}_{3} \mathrm{~B}$ with a line for the system $\mathrm{Co}+\mathrm{CO}_{2} \mathrm{~B}$ yielded a eutectoidal temperature of $845^{\circ} \mathrm{C}$.

(Received October 31, 1975)

** 姫路工業大学金属材料工学教室 (Department of Materials Science, Himeji Institute of Technology, Himeji)

* 1975 年 5 月粉体执よび粉木冶金協会東京大会に発表 